\title{
ANTS OF THE GENUS FORMICA IN THE TROPICS
}

\section{By William Morton Wheeler.}

The genus Formica belongs to the northern hemisphere and is best represented in the north temperate or subboreal zone, from which the number of species dimishes rapidly towards the pole and towards the equator. One species, Formica fusca, is so eurythermal that it and its many varieties may be said to be nearly coextensive in range with all the remaining species of the genus. Certain data recently accumulated show that through commerce a few of the species have succeeded in establishing themselves in the tropics. These data and the original distribution of the genus are briefly considered in the following paragraphs.

A map of the distribution of the genus Formica shows that it covers nearly the whole of Europe as far north as North Cape, where Sparre-Schneider (1909) has taken it between latitude $69^{\circ}$ to $70^{\circ} \mathrm{N}$., that is .within the arctic circle. In Asia the range is even wider, since it probably reaches the same high latitude and extends as far south as Soochow, China and the Himalayas $\left(28^{\circ}\right.$ to $30^{\circ} \mathrm{N}$.). A corresponding southward distribution in Europe is, of course, precluded by the Mediterranean. In the New World Formica covers most of the Nearctic Realm. I have shown (1913) that in Alaska F. fusca and its varieties marcida Wheeler and neorufibarbis Emery range at least as far north as $64^{\circ}$ to $67^{\circ}$, that is up to Fort Yukon, on the arctic circle. Eastward $F$, fusca occurs on the coast of Labrador, but no Formicidæ are known to exist in Greenland and Iceland, according to Pjetum and Lundhein, cited by Forel (1910). Prof. Pilsud, Director of the Danish Biological Laboratory on Disko Island, on the west coast of Greenland, has recently confirmed this statement in my hearing. The southern range of Formica in North America seems to stop at about $30^{\circ}$ in the United States. I have seen no specimens from Florida, but have taken a couple of species near San Antonio, Texas and several along the Mexican border in western Texas, New Mexico, 
Arizona and California. Some of these together with a few allied species occur also in Mexico, but apparently only at elevations of about $8000 \mathrm{ft}$., as far south as Hidalgo in the state of Guerrero (lat. $18^{\circ}$ ). In all probability the same Formicas inhabit the mountains of the state of Oaxaca and therefore extend the range of the genus to the southern limits of the Nearctic Realm, that is to the Isthmus of Tehuantepec.

Although there would seem to have been every opportunity both in Asia and Mexico for the spread of the species of Formica into the tropics, the only recorded instances of its occurrence are the following:

(1) Bingham in 1903 cites the taking of three workers and a female of the common European F. rufibarbis Fabr. by W. L. Distant in Pretoria, South Africa, only a short distance from the tropic of Capricorn $\left(26^{\circ} \mathrm{S}\right.$.). This seems to be the only record of the genus occuring in the southern hemisphere. There would seem to be little doubt that the species was imported directly from Europe.

(2) According to Emery F. fusca var. glebaria, a common ant in central and southern Europe, has been imported into the gardens of Algiers. He calls attention to the fact that this insect does not occur in Crete nor on the smaller islands of the Mediterranean.

(3) In 1913 Forel described a var. formosae of $F$. picea Nyl. from Taihorin, Formosa, which is on the tropic of Cancer. $F$. picea is a boreal European ant, usually found in peat-bogs. Forel's variety may perhaps occur at a considerable elevation in the mountains, which in Formosa rise to an altitude of 9000 to $14,000 \mathrm{ft}$. In this case, therefore, we may be dealing with a relict instead of a recent importation like the two previous cases. Emery believes that the $F$. fusca var. filchneri described by Forel from China is really $F$. picea.

I was astonished to find among a fine collection of ants made for me by Dr. J. W. Chapman at Dumaguete, on the island of Negros Oriental, Philippines, several specimens of two species of Formica. One of them, represented by a number of workers, agrees in all respects with European and North American 
specimens of the typical $F$. fusca, while the other, represented by four workers, is undoubtedly our common North American F. (Proformica) neogagates Emery subsp. lasioides Emery, or rather a slightly darker form approaching the var. vetula Wheeler. It seems probable that both these Formicas reached Dumaguete (lat. $9^{\circ} 30^{\prime} \mathrm{N}$.) from the United States, in merchandise imported for the Silliman Institute, at which Dr. Chapman and several other Americans are teaching.

The actual occurrence of Formica species among the tropical ant fauna is of interest in connection with the composition of certain fossil faunas like that of the Baltic Amber, which is of Lower Oligocene Tertiary age. This fauna consisted to a considerable extent of tropical genera like Tetraponera, Iridomyrmex, Oecophylla, Dimorphomyrmex, Gesomyrmex, Pseudolasius, etc., but, as I have shown (1914), it also comprised several species of Formica and notably one, $F$. flori Mayr, which is very closely related to the existing $F$. fusca. It seemed to me that in the ancient Samland these Formicas must have lived at a greater elevation than the tropical genera, but the existence of Formicas at sea-level in the Philippines seems to indicate that even during lower Oligocene times what is now a north temperate ant-genus may have shared the same habitat as the various tropical forms.

\section{Literature.}

1903 Bingham, C. T. On the Hymenoptera collected by W. L. Distant in the Transvaal, South Africa, with Descriptions of Supposed New Species. Ann. Mag. Nat. Hist. (7) 12, 1903, pp. 46-69.

1909. Emery, C. Beiträge zur Monographie der Formiciden des paläarktischen Faunengebietes VII. Deutsch. Ent. Zeitschr. 1909, pp. 179-204.

1906. Forel, $A$. Les Fourmis de L'Himalaya. Bull. Soc. Vaud. Sc. Nat. (5) 42, 1906, pp. 79-94.

1910. Forel, A. Glanures Myrmécologiques. Ann. Soc. Ent. Belg. 54, 1910, pp. 6-32. 
1913. Forel, A. H. Sauter's Formosa Ausbeute. Formicidæ II. Arch. Naturgesch. 79, 1913, pp. 183-202.

1913. Wheeler, W. M. A Revision of the Ants of the Genus Formica (Linné) Mayr. Bull. Mus. Comp. Zool. 53, 1912, pp. 379-565. 10 maps.

1914. Wheeler, W. M. The Ants of the Baltic Amber. Schrift. physik. ökon. Gesell. Königsberg 55, 1914, pp. 1-140, 66 figs.

1917. Wheeler, $W . M$. The Ants of Alaska. Bull. Mus. Comp. Zool. 61, 1917, pp. 15-22. 

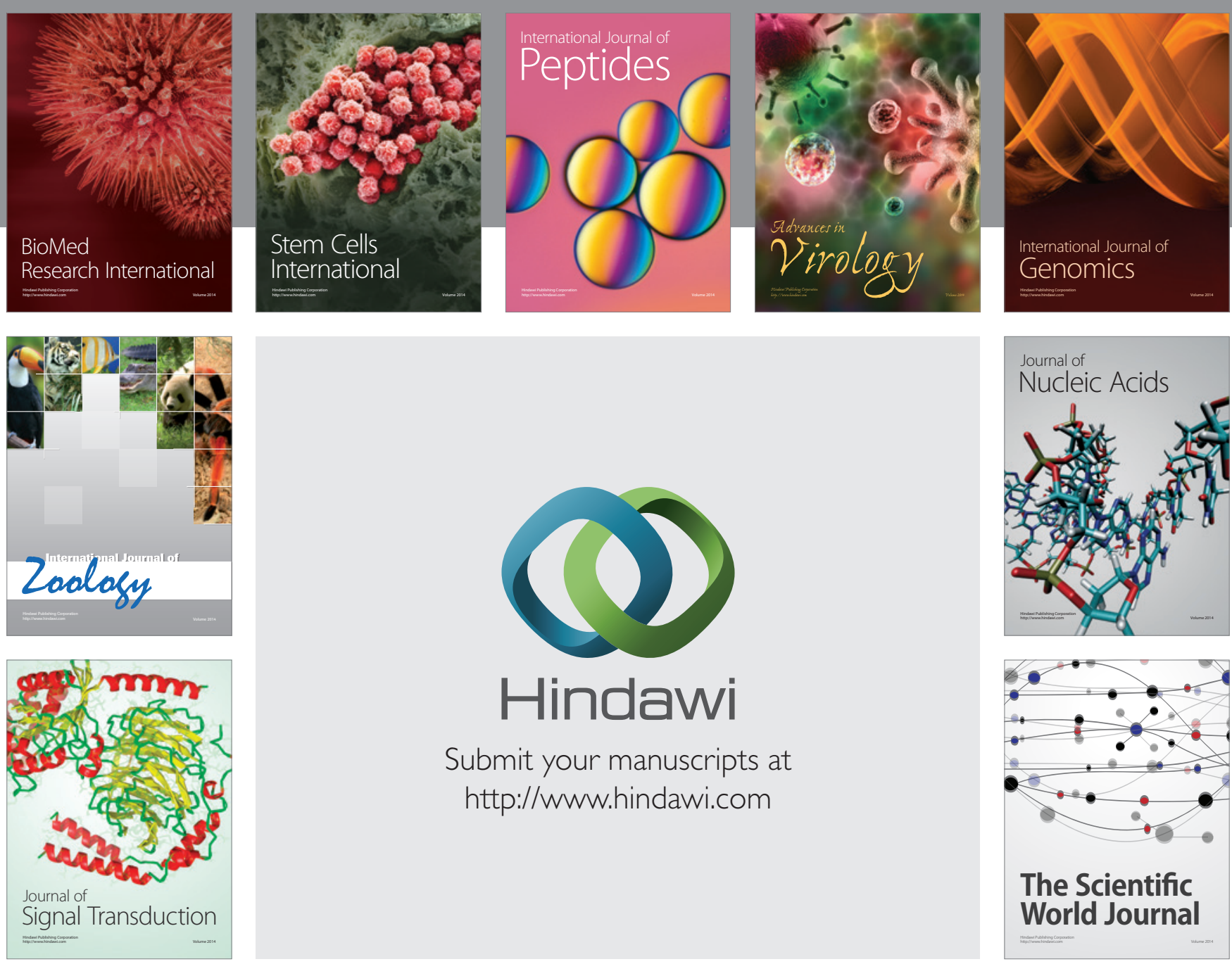

Submit your manuscripts at

http://www.hindawi.com
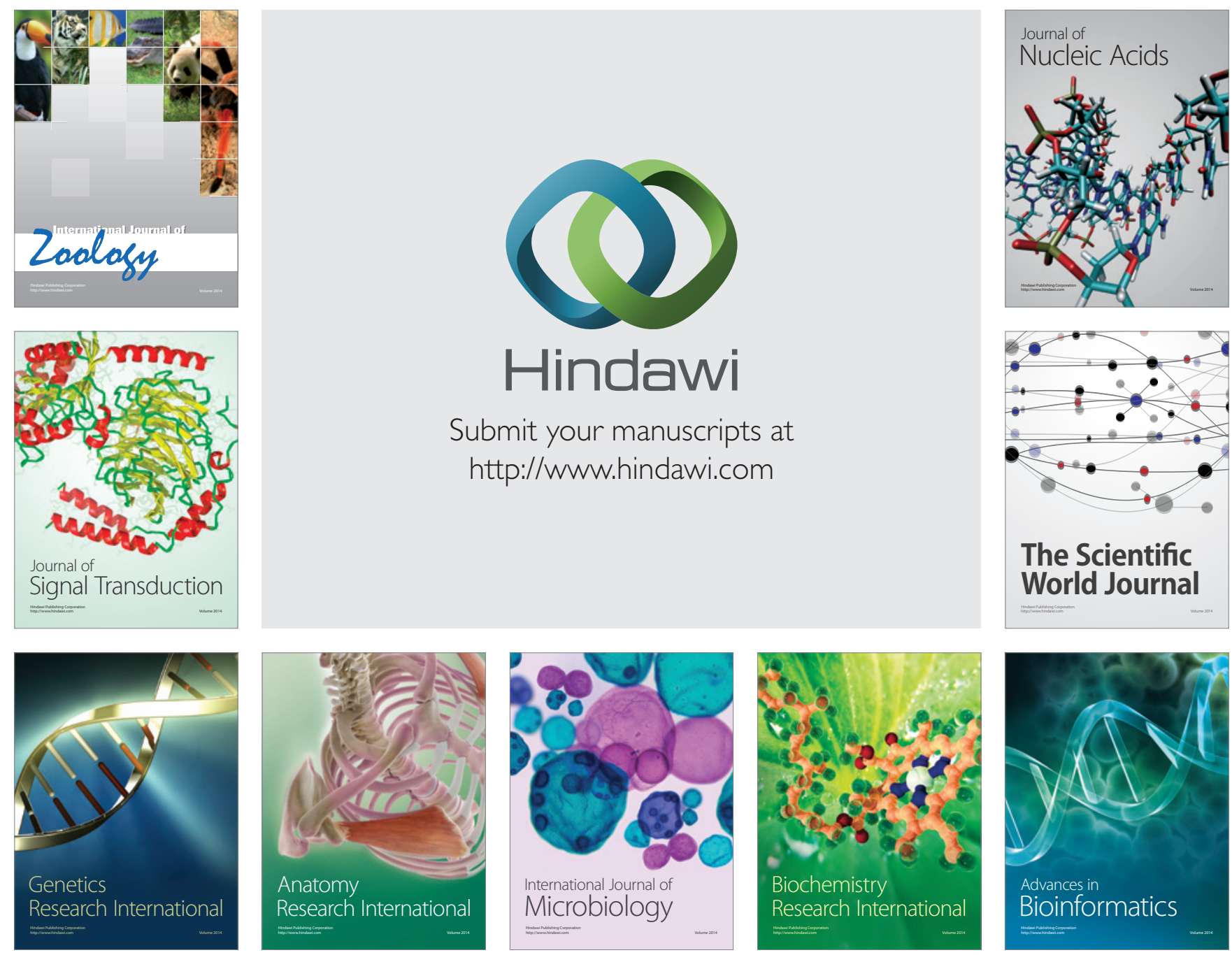

The Scientific World Journal
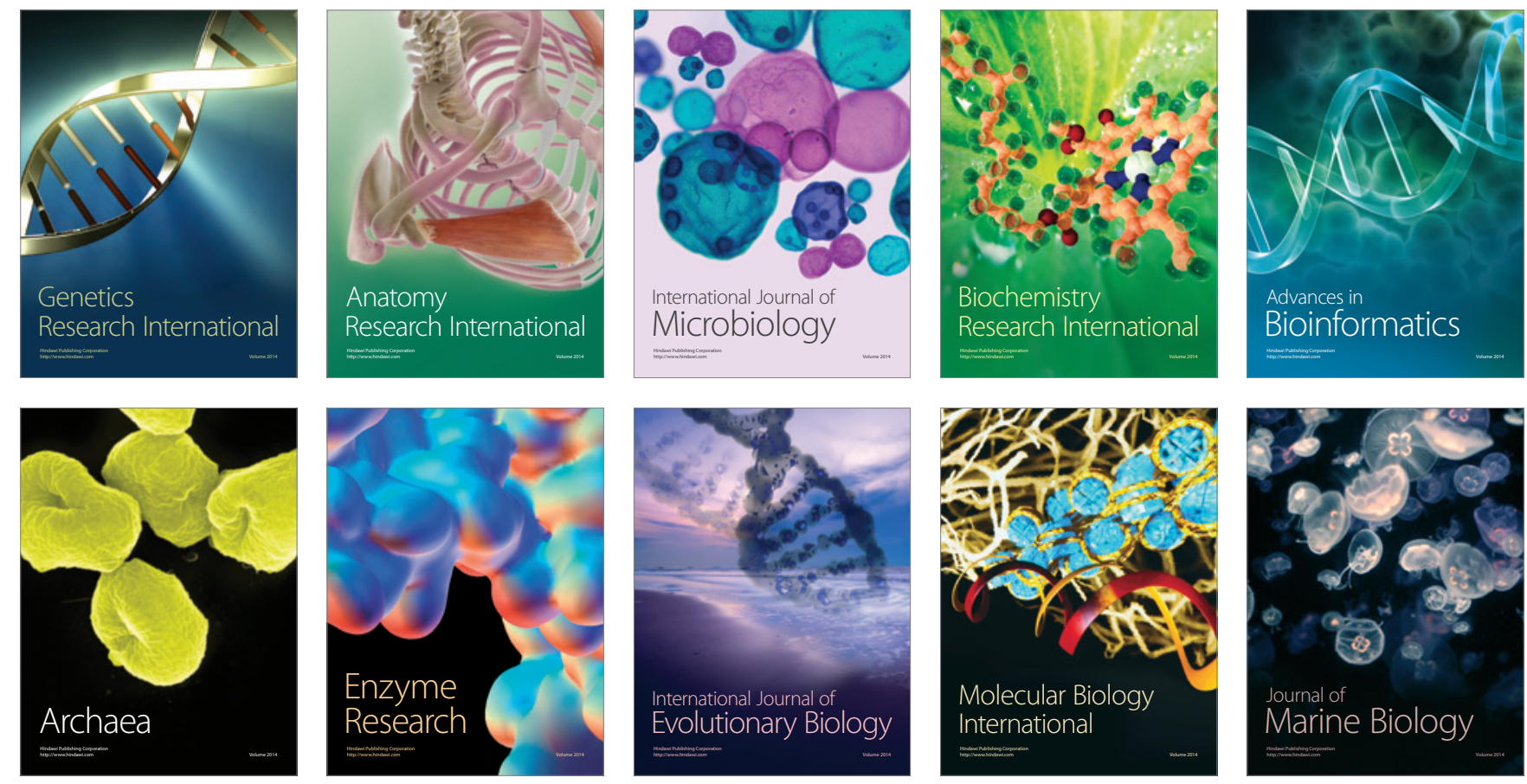